\title{
Tsunami numerical modeling and mitigation
}

\author{
Abdoullah Namdar, Asima Nusrath \\ University of Mysore, Mysore, India. \\ ab_namdar@yahoo.com;sina_a_n@yahoo.com
}

\begin{abstract}
The numerical modeling and wave theory are used in tsunami mitigation analysis. It is assumed sea forest is simulating offshore structure submitted to wave loads. The sea forest acts simulate break waves in conservation of coastal territory and facility installed over there. The result reveal that mathematical modeling and numerical simulation can be used to understand tsunami ability in design and urban construction, the research indicates reduction of water deep by sea forest resulted in reducing geometry and all wave ability.
\end{abstract}

KEYWORDS. Tsunami; Wave theory; Offshore structure; Urban design.

\section{INTRODUCTION}

7 he tsunami has brought lot of suffering to people residing in the coastal areas. An estimated 489 cities within the Pacific states of Alaska, California, Hawaii, Oregon, and Washington are susceptible to floods, cyclones and tornadoes, and as many as 900,000 residents of these cities would be inundated by a height of 50 -foot wave striking these coasts.

It has been reported by the testing of "tsunami resistant model house" that the impact on a new "tsunami resistant model house' design house was far less than that on a typical coastal house. This model was developed in the USA and now built in Sri Lanka. Digital images recorded during the test reveal how the tsunami wave passed through the new house design without damaging [1]. On the morning of Sunday, December 26, 2004 an earthquake registering 9.0 on the Richter scale struck off the western coast of North Sumatra, triggering massive waves that devastated coastal regions throughout the Indian Ocean rim. Indonesia's Aceh Province suffered the greatest mortality with widespread destruction extending along more than 1,000 kilometers of coastline. Approximately one year after the tsunami, Indonesian government estimates a total of 129,775 deaths, 38,786 missing and 504,518 tsunami-displaced in Aceh Province [2]. The implementation of urban planning and design particularly for mitigating tsunami has been applied by various researchers [3-5]. The urban design is the main and primary concept of social life.

In this investigation authors have made an attempt to mathematically calculate tsunami force and found ways to disable its force before reaching the coastline of urban area. This paper is attempting to propose method to improve urban design by utilizing the polluted coastal areas which will not only serve to increase the ecological condition by developing and implementing the concept of green belts but also serve as a barrier of the oceanic waves to enter the coast.

\section{METHODOLOGY AND MODELING}

$\mathrm{T}$ here is two methods in understanding wave force applied to the structure or to any natural barrier, the first one is application of way theory and second is using fundamental fluid dynamics equations. Here, the application of wave theory is considered. 
The winds, waves, currents, ice, earthquake, soil movement and ship collision could be analysis and modeled by mathematical method. The Morison equation could be used in estimating of wave force acting on offshore structure, it may be written as [6].

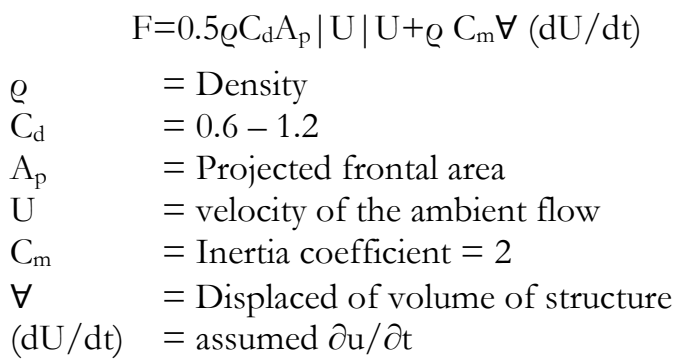

And also the Isaacson (1979) equation is complete expression for the inertial force in the X direction of wave [6].

$$
\mathrm{F}_{\mathrm{x}}=\left(\varrho \forall+\mathrm{m}_{11}\right)\left[\frac{\partial \mathrm{u}}{\partial \mathrm{t}}+\mathrm{u} \frac{\partial \mathrm{u}}{\partial \mathrm{x}}\right]+\left(\varrho \forall+\mathrm{m}_{22}\right) \mathrm{v} \frac{\partial \mathrm{v}}{\partial \mathrm{x}}+\left(\varrho \forall+\mathrm{m}_{33}\right) \mathrm{w} \frac{\partial \mathrm{w}}{\partial \mathrm{x}}+\mathrm{m}_{12}\left[\frac{\partial \mathrm{v}}{\partial \mathrm{t}}+0.5 \frac{\partial(\mathrm{uv})}{\partial \mathrm{x}}\right]+\mathrm{m}_{13}\left[\frac{\partial \mathrm{w}}{\partial \mathrm{t}}+0.5 \frac{\partial(\mathrm{uw})}{\partial \mathrm{x}}\right]+\mathrm{m}_{23}\left[0.5 \frac{\partial(\mathrm{vw})}{\partial \mathrm{x}}\right]
$$

It is assumed that the wave is bi-dimensional, $\mathrm{X}$ and $\mathrm{Y}$ being the $2 \mathrm{D}$ coordinates, all the formulae can be used in the two directions, and this maintains permanent form and also incompressible, inviscid and the flow is irrotational.

$\mathrm{L}=$ Wave length $=\mathrm{T} \sqrt{ }(\mathrm{gd})$

$\mathrm{H}=$ Wave height

$\mathrm{T}=$ Wave period

$\mathrm{Z}=\mathrm{H} / 2$

$\mathrm{C}=$ Wave speed $=(\mathrm{L} / \mathrm{T})$

Range of validity; $\quad \mathrm{Kd}<(\pi / 10)$

$(\mathrm{d} / \mathrm{L})<(1 / 20)$

$\left(\mathrm{d} / \mathrm{gT}^{2}\right)<0.0025$

$\mathrm{P}=$ Pressure $=\varrho \mathrm{gz}+0.5 \mathrm{egH} \cos \theta$

$\mathrm{E}=$ Average Energy Density $=0.125 \mathrm{ggH}^{2}$

$\mathrm{S}_{\mathrm{xx}}=$ Radiation Stress $=1.5 \mathrm{E}$

$\mathrm{S}_{\mathrm{yy}}=$ Radiation Stress $=0.5 \mathrm{E}$

$S_{x y}=S_{y x}=$ Radiation Stress $=0$

\section{RESUlts AND DisCussion}

7 he mathematical modeling and numerical simulation of wave can be performed to understand wave characteristics. The result of Tab. 1-3 and Fig. 1-3 indicate that the wave length has a direct correlation with dangerous wave effects.

\begin{tabular}{ccccccc}
\hline $\begin{array}{c}\text { Sl. } \\
\text { No }\end{array}$ & $\begin{array}{c}\text { Wave length } \\
(\mathrm{m})\end{array}$ & $\begin{array}{c}\text { Wave } \\
\text { Speed } \\
(\mathrm{m} / \mathrm{s})\end{array}$ & $\begin{array}{c}\text { Pressure } \\
\left(\mathrm{kg} / \mathrm{m}^{2}\right)\end{array}$ & $\begin{array}{c}\text { Average } \\
\text { Energy } \\
\text { Density } \\
\left(\mathrm{kg} / \mathrm{m}^{3}\right)\end{array}$ & $\begin{array}{c}\text { Radiation } \\
\text { Stress in X } \\
\text { Direction } \\
\left(\mathrm{kg} / \mathrm{m}^{2}\right)\end{array}$ & $\begin{array}{c}\text { Radiation } \\
\text { Stress in Y } \\
\text { Direction } \\
\left(\mathrm{kg} / \mathrm{m}^{2}\right)\end{array}$ \\
1 & 10 & 2.21 & 26.39 & 10.20 & 15.31 & 5.10 \\
2 & 20 & 3.13 & 52.79 & 40.83 & 61.25 & 20.41 \\
3 & 30 & 3.83 & 79.18 & 91.88 & 137.82 & 45.94 \\
4 & 40 & 4.42 & 105.58 & 163.34 & 245.01 & 81.67 \\
5 & 50 & 4.95 & 131.97 & 255.22 & 382.835 & 127.61 \\
6 & 60 & 5.42 & 158.37 & 367.52 & 551.28 & 183.76 \\
7 & 70 & 5.85 & 184.76 & 500.23 & 750.35 & 250.11 \\
8 & 80 & 6.26 & 211.16 & 653.37 & 980.05 & 326.68 \\
9 & 90 & 6.64 & 237.55 & 826.92 & 1240.38 & 413.46 \\
10 & 100 & 7 & 263.95 & 1020.89 & 1531.34 & 510.44 \\
\hline
\end{tabular}

Table 1: Mathematical Characteristics of Wave in Shallow Water. 

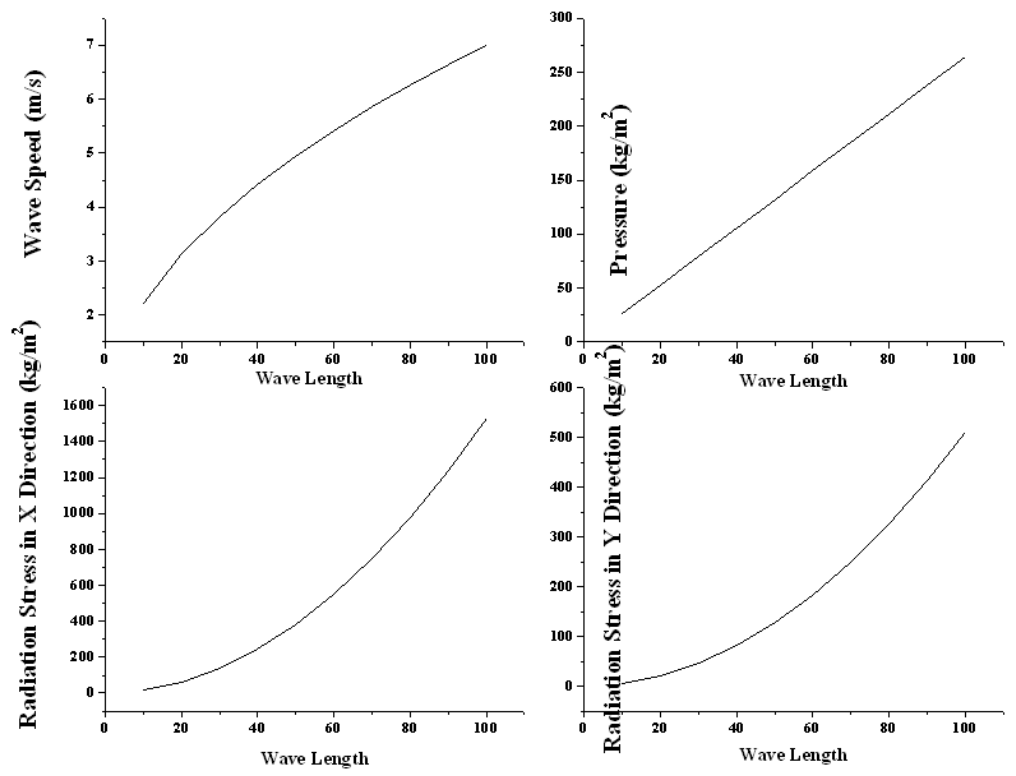

Figure 1: Mathematical characteristics of wave in shallow water.

\begin{tabular}{ccccccc}
\hline $\begin{array}{c}\text { Sl. } \\
\text { No }\end{array}$ & $\begin{array}{c}\text { Wave length } \\
(\mathrm{m})\end{array}$ & $\begin{array}{c}\text { Wave } \\
\text { Speed } \\
(\mathrm{m} / \mathrm{s})\end{array}$ & $\begin{array}{c}\text { Pressure } \\
\left(\mathrm{kg} / \mathrm{m}^{2}\right)\end{array}$ & $\begin{array}{c}\text { Average } \\
\text { Energy } \\
\text { Density } \\
\left(\mathrm{kg} / \mathrm{m}^{3}\right)\end{array}$ & $\begin{array}{c}\text { Radiation } \\
\text { Stress in X } \\
\text { Direction } \\
\left(\mathrm{kg} / \mathrm{m}^{2}\right)\end{array}$ & $\begin{array}{c}\text { Radiation } \\
\text { Stress in Y } \\
\text { Direction } \\
\left(\mathrm{kg} / \mathrm{m}^{2}\right)\end{array}$ \\
1 & 100 & 7 & 263.95 & 1020.89 & 1531.33 & 510.44 \\
2 & 200 & 9.899 & 527.90 & 4083.57 & 6125.35 & 2041.78 \\
3 & 300 & 12.12 & 791.86 & 9188.03 & 13782.05 & 4594.01 \\
4 & 400 & 14 & 1055.82 & 16334.29 & 24501.43 & 8167.14 \\
5 & 500 & 15.65 & 1319.77 & 25522.33 & 38283.49 & 12761.16 \\
6 & 600 & 17.15 & 1583.73 & 36752.15 & 55128.23 & 18376.07 \\
7 & 700 & 18.52 & 1847.68 & 50023.76 & 75035.65 & 25011.88 \\
8 & 800 & 19.8 & 2111.64 & 65337.16 & 98005.74 & 32668.58 \\
9 & 900 & 21 & 2375.59 & 82692.35 & 124038.52 & 41346.17 \\
10 & 1000 & 22.14 & 2639.55 & 102089.32 & 153133.98 & 51044.66 \\
\hline
\end{tabular}

Table 2: Mathematical characteristics of wave in shallow water.
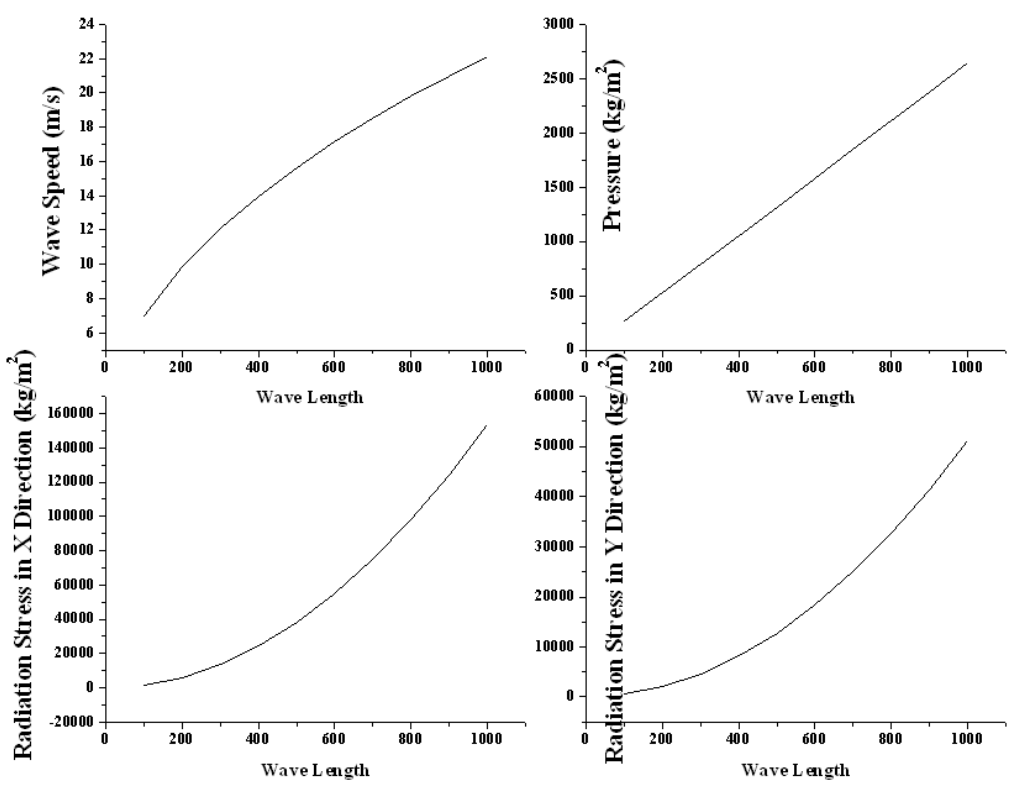

Figure 2: Mathematical characteristics of wave in shallow water. 


\begin{tabular}{ccccccc}
\hline $\begin{array}{c}\text { Sl. } \\
\text { No }\end{array}$ & $\begin{array}{c}\text { Wave length } \\
(\mathrm{m})\end{array}$ & $\begin{array}{c}\text { Wave } \\
\text { Speed } \\
(\mathrm{m} / \mathrm{s})\end{array}$ & $\begin{array}{c}\text { Pressure } \\
\left(\mathrm{kg} / \mathrm{m}^{2}\right)\end{array}$ & $\begin{array}{c}\text { Average } \\
\text { Energy } \\
\text { Density } \\
\left(\mathrm{kg} / \mathrm{m}^{3}\right)\end{array}$ & $\begin{array}{c}\text { Radiation } \\
\text { Stress in X } \\
\text { Direction } \\
\left(\mathrm{kg} / \mathrm{m}^{2}\right)\end{array}$ & $\begin{array}{c}\text { Radiation } \\
\text { Stress in Y } \\
\text { Direction } \\
\left(\mathrm{kg} / \mathrm{m}^{2}\right)\end{array}$ \\
1 & 1000 & 22.14 & 2639.55 & 102089.323 & 153133.98 & 51044.66 \\
2 & 2000 & 31.3 & 5279.09 & 408357.29 & 612535.93 & 204178.64 \\
3 & 3000 & 38.34 & 7918.64 & 918803.90 & 1378205.85 & 459401.95 \\
4 & 4000 & 44.27 & 10558.2 & 1633429.16 & 2450143.74 & 816714.58 \\
5 & 5000 & 49.5 & 13197.75 & 2552233.06 & 3828349.59 & 1276116.53 \\
6 & 6000 & 54.22 & 15837.3 & 3675215.61 & 5512823.41 & 1837607.80 \\
7 & 7000 & 58.57 & 18476.85 & 5002376.81 & 7503565.20 & 2501188.40 \\
8 & 8000 & 62.61 & 21116.4 & 6533716.64 & 9800574.96 & 3266858.32 \\
9 & 9000 & 66.41 & 23755.95 & 8269235.13 & 12403852.69 & 4134617.56 \\
10 & 10000 & 70 & 26395.50 & 10208932.3 & 15313398.39 & 5104466.12 \\
\hline
\end{tabular}

Table 3: Mathematical Characteristics of Wave in Shallow Water.
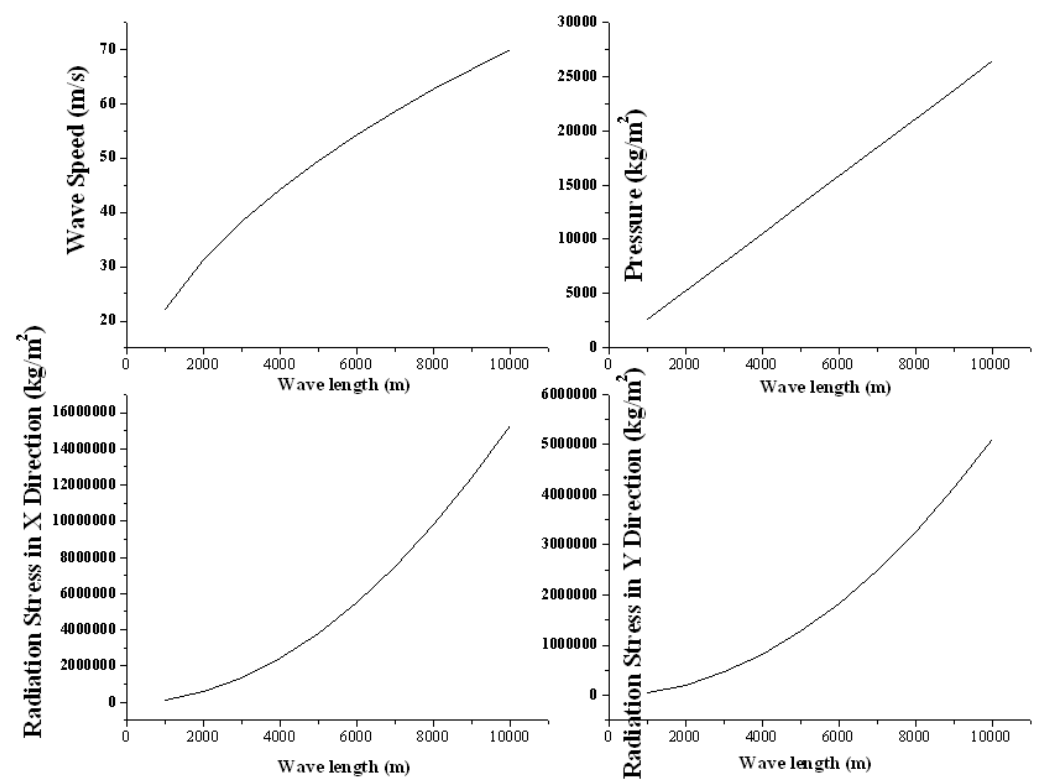

Figure 3: Mathematical characteristics of wave in shallow water.

To reduce of wave length as per mathematical equation, one way is to reduce the water depth, this subsequently leads to reduction geometry and all dangerous wave effects.

The Bandarabbas city of Iran with geographical condition placed in front of the Geshm Island with minimum of $1 \mathrm{~km}$ distance. This geographical position increases tsunami wave if it occur between the Geshm Island of $120 \mathrm{~km}$ length and BandarAbbas coastal, this is a factor make complicate tsunami wave behavior. This geographical condition could be bringing back wave from one coastal to other (Fig 4).

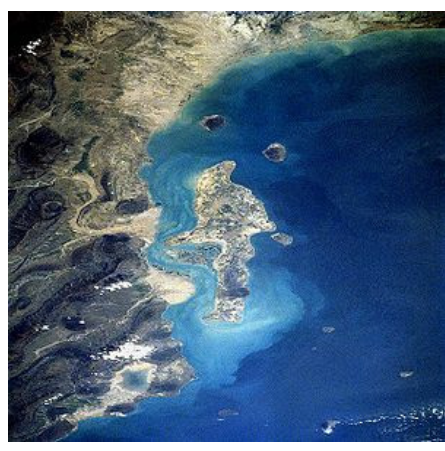

Figure 4: Satellite image of Persian Gulf.

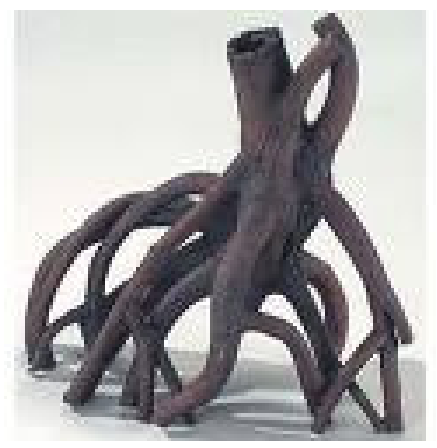

Figure 5: Mangrove root shape. 
The mangrove root shape (Fig 5) is similar coarse aggregate, this shape increases soil foundation bearing capacity and tree stability and this could control land slide, deformation, settlement and increases soil cohesion which is needed in standing of trees subjected to dynamic force. The mangrove root strength can be find from laboratory experiments: the process is statistic and experimental is similar to approach other construction material such as steel. The advantage of coastal area is mangrove root not affect to any structure foundation. Density of mangrove jungle is depending on plan the height of mangrove could be reach average up to $15 \mathrm{ft}$, all assumption can be lead to reach a hypothesis for considering jungle as a solid area in wave height reduction.

Another idea about mangrove in tsunami mitigation is similarity to dense wall installed in subsoil for reduction of dynamic stress created under shaking table function this method reduces soil deformation mitigation as well as seismic force. The mangrove root function in tsunami is simulate soil nailing or micro pile in ground stabilization and improvement, this reduce all kind of geotechnical problem faces subsoil during the tsunami, this is simulate of passing vehicle on the subsoil which create of dynamic force at any moment.

The mathematically calculation water self weight shown in Fig. 6, it is exhibited reducing the lateral pressure of water in the static position if area have been under plantation, it is clear the tsunami is in the dynamic form, and need of calculation of tsunami speed reduction, it has direct correlation with strength, diameter, root, height, density and body tree. The soil texture has independently affect in stability of tree which soil consists of clay mineral with high level of cohesion helps in standing tree submitted to the dynamic force.
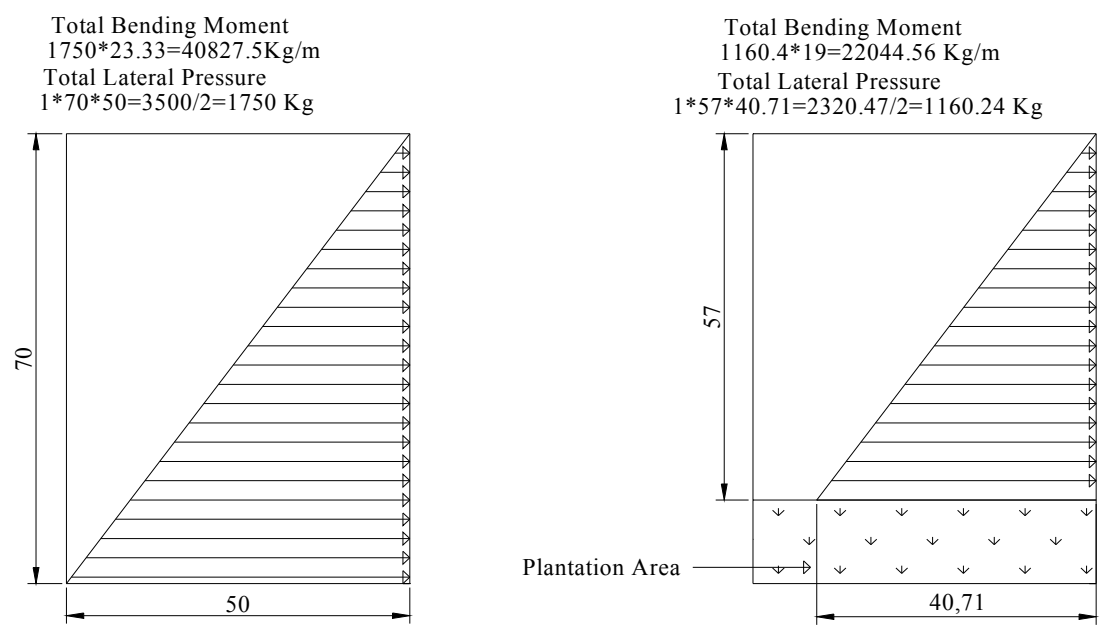

Figure 6: Water force model before and after plantation.

The figures 7-9 are shown different types of mangrove. Due to creation of jungle, the urban area take advantage of approaching better environment, The another advantage of this urban design method is to have an attractive tourist place with job creation and it lead to improve of economically development of coastal region. In the coastal territory with land shortage for green belt, this method is applicable and will have significantly affect on maintain of climate which is one of the important problem in recent century society faces.

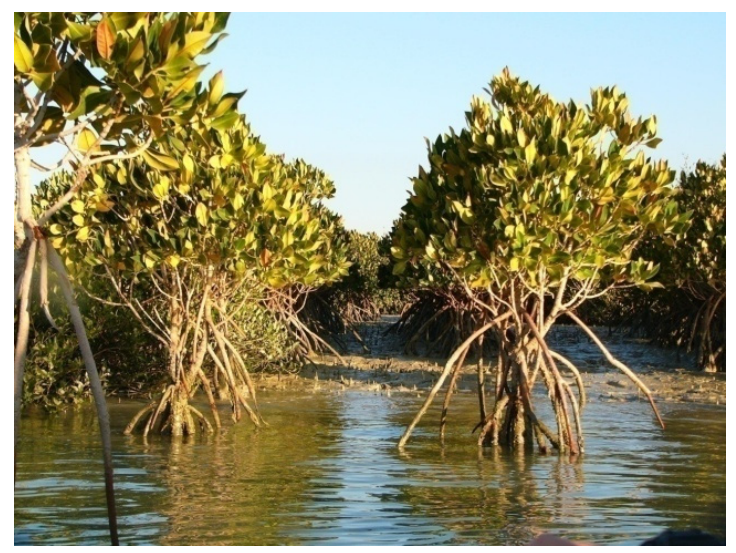

Figure 7: Mangrove tree in coastal area. 


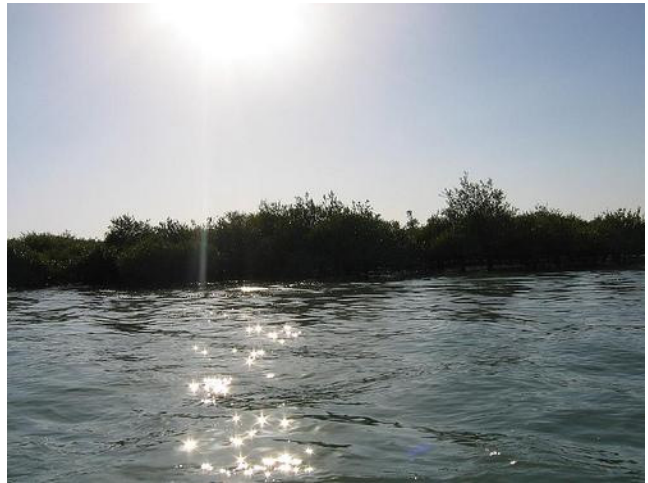

Figure 8: Mangrove tree in coastal area.

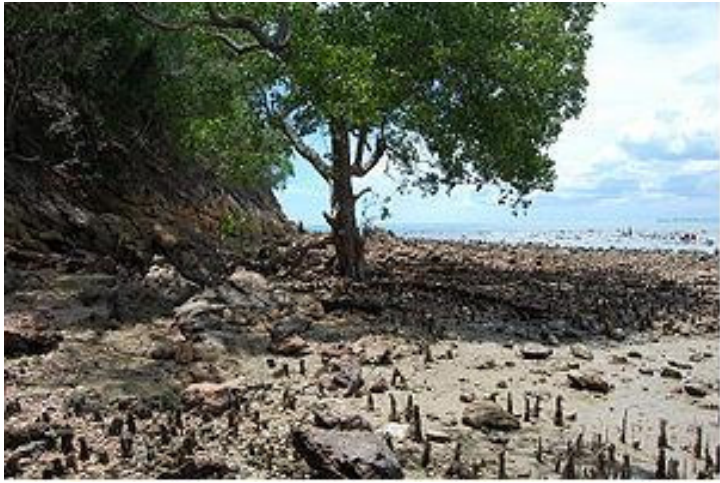

Figure 9: Mangrove tree in coastal area.

\section{CONCLUSION}

- The result reveals mathematical modeling and numerical simulation could be used to understand dangerous wave effects in design and urban construction.

- The research indicates reduction of water deep by sea forest results in reducing geometry and all dangerous wave effects.

- The method could be applied in reduction of air pollution and the control of tsunami force.

- The method will create attractive tourist places.

- The method is fruitful to develop the economy of coastal regions.

- If the tsunami not occur in the region the society could use advantage of the improvement of climate.

- It is possibility to have green belt in the coastal territory if faces of land shortage.

\section{REFERENCES}

[1] I. Proce Navaratnam et al., Civil Engineering, 161 (2008) 77.

[2] United Nations Information Management Service (UNIMS) in collaboration with the Rehabilitation and Reconstruction Agency (BRR). Tsunami Recovery Status Report, 8 December 2005

[3] FIG. The Contribution of the Surveying Profession to Disaster Risk Management, A publication of FIG Working Group 8.4 International Federation of Surveyors (FIG) (2006).

[4] M. Pelling, The vulnerability of cities: natural disasters and socialresilience, London: Earthscan Publications (2003).

[5] JICA. The Study on the Urgent Rehabilitation and Reconstruction Support program for AcehProvince and Affected Areas in North Sumatra. Japan International Cooperation Agency (JICA), Badan Perencanaan Pembangunan Nasional (Bappenas), and Provincial Government of Nanggroe Aceh Darussalaam, Banda Aceh Working report (2005).

[6] T. Sarpkaya, M. Isaacson, Mechanics of wave forces on offshore structures, Van Nostrand Reinhold Co, (1981) 295. 